International Journal of Economics, Business and Accounting Research (IJEBAR)

Peer Reviewed - International Journal

Vol-4, Issue-2, 2020 (IJEBAR)

E-ISSN: 2614-1280 P-ISSN 2622-4771

https://jurnal.stie-aas.ac.id/index.php/IJEBAR

\title{
THE EFFECT OF EFICIENCY RATIO, EFFECTIVENESS RATIO, CONTRIBUTION RATIO OF LAND AND BUILDING TAX ON LOCAL OWN SOURCE REVENUE IN SUKOHARJO REGENCY 2016-2018 (EMPIRICAL STUDY OF THE REGIONAL FINANCE AGENCY IN SUKOHARJO REGENCY)
}

\author{
Setyani Sri Haryanti1, Febrian Fernanda Siwi Tatok2, Irwan Christanto Edy3 \\ Akuntansi, STIE Adi Unggul Bhirawa Surakarta \\ Email:setyani_pemnas@ymail.com \\ Fernandafebrian3@gmail.com \\ irwan_aub@yahoo.co.id
}

\begin{abstract}
This study aims to determine the effect of the efficiency ratio of Land and Building Tax (PBB) revenue, determine the effect of the effectiveness ratio of Land and Building Tax (PBB) revenue and determine the effect of the ratio of contribution of Land and Building Tax (PBB) revenue to Regional Original Revenue (PAD) in Sukoharjo Regency in 2016-2018. The data analysis technique in this study is a descriptive analysis using indicators of the criteria of efficiency, effectiveness and contribution. The type of data used is quantitative data, data sources used secondary data and use the documentation method. The results of the study note that the efficiency ratio of land and building tax receipts in Sukoharjo regency in 2016-2018 is included in the very efficient criteria because in those 3 years the realization of land and building tax (PBB) revenues is greater than the cost of collection. The effectiveness ratio of revenue from land and building tax (PBB) in Sukoharjo Regency in 2016-2018 is included in the very effective criteria because the average for 2016-2018 is more than $100 \%$, namely $123.93 \%$ with details in 2016 of $131.41 \%$, in 2017 it was $120.35 \%$ while in 2018 it was $120.02 \%$. The contribution ratio of the Land and Building Tax to Local Own Revenue (PAD) in Sukoharjo Regency in 2016-2018 is included in the criteria of lacking because the ratio of contributions on average is only $10.71 \%$.
\end{abstract}

Keywords: $\quad$ Land and Building Tax (PBB), Efficiency, Effectiveness, Contribution.

\section{Introduction}

The welfare of the community in each region requires sources of financing both from the center and from the Regional Original Revenue (PAD). This funding source will have a positive impact on the people in increasing economic growth. Regional revenue is derived from the results of regional levies as well as regional taxes in managing regional assets that are separated so that it can provide freedom to the regions in exploring funding and implementing regional autonomy as an embodiment of decentralization. Funding in question is a determinant in knowing whether or not a government is smooth. Community services are hampered if the ability in funding is limited so that it can lead to services that are not optimal. According to Datu (2012), Local Own Revenue (PAD) is very important in the implementation of development, because these funds are owned by the regional government itself, so that the regional government has full authority to manage these funds. One source of Regional Original Revenue (PAD) that is relied on by local governments is revenue that comes from the local tax sector.

Regional Tax and Regional Retribution is a component of Local Revenue (PAD) which has an important role. Local governments should have knowledge and be able to identify sources of potential Local Revenue (PAD), especially Regional Taxes and Regional Retribution. If potential Local Taxes are not managed and considered, their management will not be effective and efficient so that it can 
International Journal of Economics, Business and Accounting Research (IJEBAR)

Peer Reviewed - International Journal

Vol-4, Issue-2, 2020 (IJEBAR)

E-ISSN: 2614-1280 P-ISSN 2622-4771

https://jurnal.stie-aas.ac.id/index.php/IJEBAR

harm the community and local government as a collector because local taxes and levies are not about the target and the realization of optimal local revenue (Handoko: 2013)

Land and Building Tax (PBB) is a tax on land and buildings, both owned, acquired and controlled. In order for the government to be more effective and efficient in carrying out government operations and development, it is necessary to establish a mechanism for managing policies with the authority given to financing. The earth and buildings are two objects of the United Nations, namely the earth which can be defined as the surface of the earth in the form of land and water and everything below it, while the building is a technical construction that is implanted or permanently attached to the land and waters in the territory of Indonesia. (Mokamat: 2009). Data from the Sukoharjo District Government Financial Report on Realization of Land and Building Tax (PBB) Revenues showed an increase in 2014-2017 and decreased slightly in 2018 as in Table 1 and Graph 1 below:

Table 1. Realization of PBB revenues in Sukoharjo Regency in 2016-2018

\begin{tabular}{|c|c|}
\hline Year & $\begin{array}{c}\text { Realization of UN revenues } \\
(\mathrm{Rp})\end{array}$ \\
\hline 2014 & $29,519,284,204$ \\
\hline 2015 & $31,680,799,406$ \\
\hline 2016 & $35,480,427.946$ \\
\hline 2017 & $36,104,224,831$ \\
\hline 2018 & $36,005,474,311$ \\
\hline \multicolumn{2}{|c|}{ Source: (BKD Sukoharjo Regency) } \\
\hline
\end{tabular}

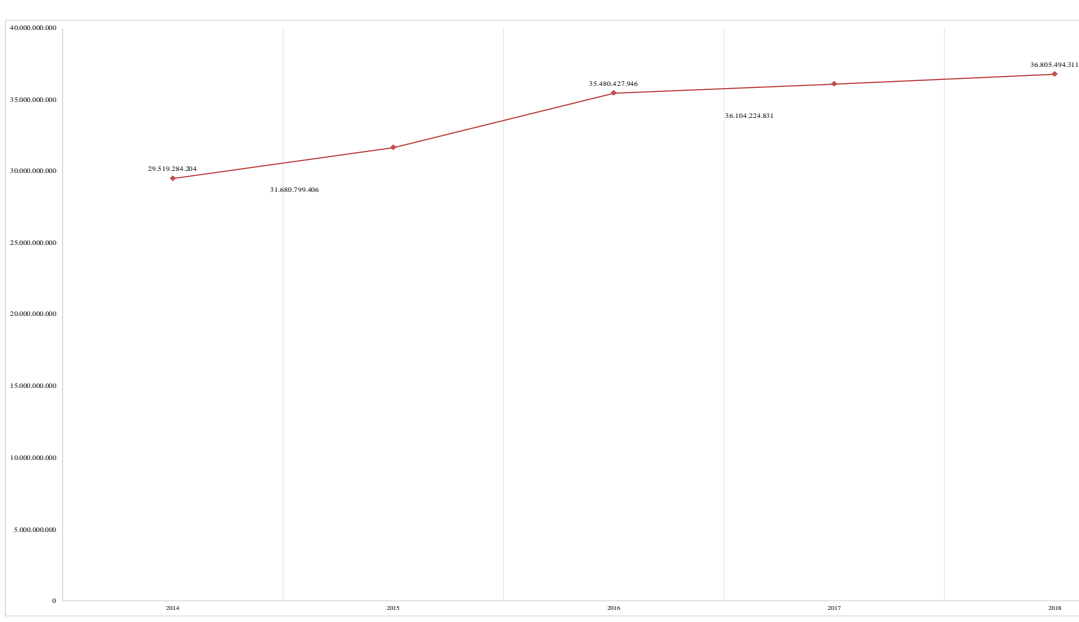

Graph 1. Increase and decrease of PBB realization in Sukoharjo Regency in 2014-2018

The Efficiency Ratio can be illustrated through the efficiency of expenditure in realizing planned Local Revenue (PAD) and compared to the target set based on the real potential. Efficiency is the cost that is used by local governments in providing services with the aim of getting a decent profit on the process of collecting Regional Taxes and Regional Levies which are then compared to the total profits and comparison with targets. Hasnanti Agustin Rahayu and Abdul Halim's (2016) research stated that the efficiency of the Land and Building Tax (PBB) in Buleleng Regency in 2012 and 2011 was 2.99\% and $0.87 \%$ with very efficient criteria. That is because all costs of managing the Land and Building Tax (PBB) have been expensed to local governments with the largest percentage of absorption of 
International Journal of Economics, Business and Accounting Research (IJEBAR)

Peer Reviewed - International Journal

Vol-4, Issue-2, 2020 (IJEBAR)

E-ISSN: 2614-1280 P-ISSN 2622-4771

https://jurnal.stie-aas.ac.id/index.php/IJEBAR

costs is employee expenditure by $95.61 \%$. Ma'ruf and Supatminingsih (2020) conducted a research in Sukoharjo District showing that taxpayer awareness, tax sanctions, tax understandings, and service quality simultaneously had a positive effect on land and building tax compliance.

Effectiveness Ratios according to Handoko (2013) are ratios that illustrate the ability of local governments to realize Local Revenue (PAD) obtained and compared with a budget determined based on the real potential of the region, the higher the effectiveness ratio, the better the performance of the government. Puspitasari (2014) Effectiveness is the success or failure of an organization in achieving its goals. Halim (2014) suggests that the analysis of local tax effectiveness is an analysis that illustrates the ability of local governments in realizing planned Local Revenue (PAD) compared to targets set based on the real potential of the region. Research by Raudhatun Wardhani and Wida Fadhila (2017) states that the effectiveness of Land and Building Tax (PBB) revenue in Aceh Besar District has increased annually with an average of $100.10 \%$ and is categorized as very efficient because the government is doing various ways in increasing revenue of the Earth Tax and Building (PBB), which is by collecting data on tax subjects and objects.

Contribution analysis is used to find out how big the role of all regional revenue (Regional Tax) is in increasing Local Original Revenue (PAD), so that with this data can provide a clear picture of the actions or policies that must be done by local governments in an effort to increase the role of all revenue the area (Micah, 2010). Contribution is the figure given by the Regional Tax on the total amount of the Regional Original Revenue (PAD) achieved and the figure on the target set. Analysis of contribution is the ratio of Local Own Revenue (PAD) in t years with regional revenue in the same year. Research by Nur Anisa, Elva Nuraina and Liana Vivin Wihartanti (2019) stated that the contribution of land and building tax (PBB) revenues in 2014-2018 in Magetan Regency was classified as less with an average of $10.08 \%$, this is due to the receipt of land and land tax The building (PBB) compared to the Regional Original Revenue (PAD) is very small and there has not been an update and updating of the tax object and its lack of tax payers in Magetan Regency.

Based on the phenomena, theoretical basis and the gap of the results of previous studies, the researchers conducted this study to reexamine the effect of the Efficiency Ratio, Effectiveness Ratio and Ratio of Land and Building Tax Contributions (PBB) to Sukoharjo Regency's Original Local Revenue (PAD) in 2016-2018. The formulation of the problem is as follows:

a. What is the level of efficiency ratio of Land and Building Tax (PBB) revenue in Sukoharjo Regency in 2016-2018?

b. What is the level of effectiveness ratio of Land and Building Tax (PBB) revenue in Sukoharjo Regency in 2016-2018?

c. What is the level of contribution ratio of Land and Building Tax (PBB) revenue to Local Own Revenue (PAD) in Sukoharjo Regency in 2016-2018?

This study aims to determine the effect of the Efficiency Ratio, Effectiveness Ratio, Ratio of Land and Building Tax Contributions (PBB) to Regional Original Revenue (PAD) of Sukoharjp Regency in 2016-2018. The results of this study are expected to make reference material in making decisions in order to be able to increase efficiency, effectiveness and contribution to the realization of the tax from the Land and Building Tax (PBB) and to be considered by the Sukoharjo regional government and the Regional Financial Board of Sukoharjo Regency to increase Regional Revenue (PAD) from the Land and Building Tax (PBB) and can add reference materials and insights on the efficiency, effectiveness and contribution of the Land and Building Tax (PBB) to Regional Original Revenue (PAD) for future researchers.

\section{Method}

This type of research used in this study is a descriptive research method by applying the calculation of efficiency ratios, effectiveness ratios and contribution ratios. The type of data used in this study is quantitative data in the form of Land and Building Tax Collection Costs, Realization of Land and Building Tax Revenues, Target of Land and Building Tax Revenues and Realization of Regional Tax 
International Journal of Economics, Business and Accounting Research (IJEBAR)

Peer Reviewed - International Journal

Vol-4, Issue-2, 2020 (IJEBAR)

E-ISSN: 2614-1280 P-ISSN 2622-4771

https://jurnal.stie-aas.ac.id/index.php/IJEBAR

Revenues (P AD). The data source used in this study is secondary data. The technique used in data collection is the documentation method, while the data that will be obtained from the Regional Finance Agency of Sukoharjo Regency is the realization of the 2015-2018 budget revenue and expenditure budget realization report. The data analysis used in this study are as follows:

1. Efficiency Ratio

Efficiency ratio is a ratio that illustrates the ratio between the amount of costs incurred to obtain revenue with the realization of income received. With the following formula

$$
\text { Rasio Efisiensi }=\frac{\text { Biaya Pemungutan PBB }}{\text { Realisasi penerimaan PBB }} \times 100 \%
$$

Table 2. Criteria of the value of a tax efficiency

\begin{tabular}{|c|c|}
\hline $\begin{array}{c}\text { PERCENTAGE } \\
(\%)\end{array}$ & CRITERIA \\
\hline$<5$ & Very efficient \\
\hline $5-10$ & Efficient \\
\hline $11-20$ & Efficient enough \\
\hline $21-30$ & Inefficient \\
\hline$>30$ & Not efficient \\
\hline
\end{tabular}

Source: Minister of Home Affairs No.690,900,327

2. Effectiveness Ratio

The level of effectiveness ratio can be known from the results of calculating the effectiveness formulation. The formula for measuring effectiveness related to taxation is the comparison between tax realization and tax targets. The formula used in calculating the level of effectiveness of receipts of Earth and Buildings (PBB):

$$
\text { Rasio Efektivitas }=\frac{\text { Biaya Penerimaan PBB }}{\text { Target Penerimaan PBB }} \times 100 \%
$$

Table 3. Criteria for the value of an effective tax item

\begin{tabular}{|c|c|}
\hline $\begin{array}{c}\text { PERCENTAGE } \\
(\%)\end{array}$ & CRITERIA \\
\hline$>100$ & Very effective \\
\hline 100 & E fektif \\
\hline $90-99$ & Enough Effective \\
\hline $75-89$ & Less effective \\
\hline$<75$ & Not effective \\
\hline
\end{tabular}

Sumbe r: Kepmendagri No.690,900,327

3. Contribution Ratio

Contributions can be interpreted as contributions made from the Land and Building Tax (PB B) on Regional Original Revenue (PAD). If the government can optimize the source of revenue from land and building tax (PBB) and the potential for revenue is getting higher, the contribution to regional original income will increase. To find out how much the contribution of land and building tax (PBB) to regional original income (PAD) can use the following formula :

$$
\text { Rasio Kontribusi }=\frac{\text { Realisasi Penerimaan } P B B}{\text { Realisusi Penerimaan } P A D} X 100 \%
$$

Table 4. Criteria of the value of a tax contribution

\begin{tabular}{|c|c|}
\hline $\begin{array}{c}\text { PERCENTAGE } \\
(\%)\end{array}$ & CRITERIA \\
\hline
\end{tabular}


International Journal of Economics, Business and Accounting Research (IJEBAR)

Peer Reviewed - International Journal

Vol-4, Issue-2, 2020 (IJEBAR)

E-ISSN: 2614-1280 P-ISSN 2622-4771

https://jurnal.stie-aas.ac.id/index.php/IJEBAR

\begin{tabular}{|c|c|}
\hline $0.00-10$ & Very less \\
\hline $10,10-20$ & Less \\
\hline $20.10-30$ & S edang \\
\hline $30.10-40$ & Pretty good \\
\hline $40.10-50$ & Good \\
\hline$>50$ & Very good \\
\hline
\end{tabular}

Source: Minister of Home Affairs No.690,900,327

\section{Research Result}

\subsection{Realization of Land and Building Tax (PBB) in Sukoharjo Regency 2016-2018}

Before seeing how much the efficiency ratio, the ratio of effectiveness and the ratio of contributions to Regional Original Revenues in Sukoharjo Regency in 2016-2018, the authors first describe the target data and realization of land and building tax revenues and Regional Original Revenues in Sukoharjo Regency in 2016-2018 obtained from the Regional Finance Board of Sukoharjo Regency as follows:

Table 5. Target and Realization of Sukoharjo Regency Land and Building Tax

in 2016-2018

\begin{tabular}{|c|c|c|}
\hline Year & $\begin{array}{c}\text { UN target } \\
(\mathrm{Rp})\end{array}$ & $\begin{array}{c}\text { United Nations realization } \\
(\mathrm{Rp})\end{array}$ \\
\hline 2016 & $27,000,000,000$ & 35480.427 .946 \\
\hline 2017 & $30,000,000,000$ & $36,104,224,831$ \\
\hline 2018 & $30,000,000,000$ & $36,005,474,311$ \\
\hline
\end{tabular}

Source: (BKD Sukoharjo Regency)

The table above shows that the realization of the Land and Building Tax (PBB) in 2016-2017 increased by Rp. $623,796,885$ and in 2017-2018 decreased by Rp. $98,750,520$ but all the target numbers have been reached. In 2016 the realization of the Land and Building Tax (PBB) of Rp. 35,480,427,946 reached the set target of Rp. 27,000,000.000. In 2017 the realization of the Land and Building Tax (PBB) of Rp. 36,104,224,831 achieve the targets set amount Rp. 30,000,000,000. whereas in 2018 the realization of the Land and Building Tax (PBB) of Rp. 36,005,474,311 reached the set target of Rp. 30,000,000,000.

\subsection{Target and Realization of Local Own Revenue (PAD) in Sukoharjo Regency in 2016-2018}

Table 6. Target and Realization of Original Revenue of Sukoharjo District in 2016-2018

\begin{tabular}{|c|c|c|}
\hline Year & $\begin{array}{c}\text { PAD target } \\
(\mathrm{Rp})\end{array}$ & $\begin{array}{c}\text { Realization of PAD } \\
(\mathrm{Rp})\end{array}$ \\
\hline 2016 & $314,896,567,000$ & $335,071,057,676$ \\
\hline 2017 & $325,754,795,000$ & $395,975,464,962$ \\
\hline 2018 & $348,388,683,000$ & $433,485,481,219$ \\
\hline
\end{tabular}

Source: (BKD Sukoharjo Regency)

The table above shows that the realization of regional own-source revenue (PAD) in Sukoharjo Regency in 2016-2018 always increased from year to year. In 2016-2017 the amount is Rp. 60,904,407,286 and in 2017-2018 amounting to Rp. 37,510,016,257 and achieved the target set in 2016 the realization of Local Original Opinions (PAD) of Rp. 335,071,057,676 have reached the set target of Rp. 3 14,896,567,000, in 2017 the realization of Regional Original 
International Journal of Economics, Business and Accounting Research (IJEBAR)

Peer Reviewed - International Journal

Vol-4, Issue-2, 2020 (IJEBAR)

E-ISSN: 2614-1280 P-ISSN 2622-4771

https://jurnal.stie-aas.ac.id/index.php/IJEBAR

Income (PAD) of Rp. 395,975,464,962 have reached the set target of Rp. 325,754,795,000, whereas in 2016 the realization of Regional Original Revenue (PAD) of Rp. 433,485,481,219 have reached the target set at Rp. 348,388,683,000.

\section{Discussion}

4.1 The Effect of Land and Building Tax (PBB) Efficiency Ratio in Sukoharjo Regency in 2016-2018

Land and Building Tax (PBB), which is part of the Balancing Fund where the source is from the State Budget consisting of Revenue Sharing Funds (DBH), General Allocation Funds (DAU) and Special Allocation Funds (DAK). When the Land and Building Tax is managed by the central government the collection fee is set at 9\% based on Law No. 28 of 2009. After the transfer and managed by the regional government the amount of the collection fee is regulated by Government Regulation No. 69 Thun 2010 amounted to 5\% of the target or determination. If the calculation of the efficiency of the Land and Building Tax (PBB) results in a percentage not exceeding 5\%, then the Land and Building Tax (PBB) is included in the very efficient criteria or the receipt of the Land and Building Tax in Sukoharjo Regency is very good and if the result is more than $30 \%$ then included in the inefficient criteria. P CALC efficiency ratio and Building Tax (PBB) in Sukoharjo Year 2016-2018.

a. In 2016

$$
\frac{\text { Rp. } 1.350 .000 .000}{\text { Rp. } 35.480 .427 .946} x 100 \%=3,80 \%
$$

b. 2017

$$
\frac{\text { Rp. } 1.500 .000 .000}{\text { Rp. } 36.104 .224 .831} \times 100 \%=4,15 \%
$$

c. 2018

$$
\frac{\text { Rp. } 1.500 .000 .000}{\text { Rp. } 36.005 .474 .311} \times 100 \%=4,16 \%
$$

The magnitude of the level of efficiency ratio of Land and Building Tax (PBB) revenue from 2016-2018 can be seen in table 7.

Table 7. Sukoharjo Regency Land and Building Tax Efficiency Ratio in 2016-2018

\begin{tabular}{|c|c|c|c|c|}
\hline Year & $\begin{array}{c}\text { United Nations } \\
\text { Collection Fee } \\
(\mathrm{Rp})\end{array}$ & $\begin{array}{c}\text { United Nations } \\
\text { realization } \\
(\mathrm{Rp})\end{array}$ & $\begin{array}{c}\text { Efficiency } \\
\text { Ratio } \\
(\%)\end{array}$ & Criteria \\
\hline 2016 & $1,350,000,000$ & $35,480.427,946$ & 3.80 & Very efficient \\
\hline 2017 & $1,500,000,000$ & $36,104,224,831$ & 4.15 & Very efficient \\
\hline 2018 & $1,500,000,000$ & $36,005,474,311$ & 4.16 & Very efficient \\
\hline \multicolumn{3}{|c|}{ Average } & 4.04 & Very efficient \\
\hline
\end{tabular}

Source: (Regional Finance Agency of Sukoharjo Regency)

Based on table 7 and the results of the calculation of the effectiveness ratio of Land and Building Tax (PBB) in Sukoharjo Regency in 2016-2018 can be explained as follows:

a. In 2016 the cost of collecting the Land and Building Tax (PBB) was set at Rp. 1,350,000,000 with the realization of Land and Building Tax (PBB) revenue of Rp. 35,480,427,946 and the 
International Journal of Economics, Business and Accounting Research (IJEBAR)

Peer Reviewed - International Journal

Vol-4, Issue-2, 2020 (IJEBAR)

E-ISSN: 2614-1280 P-ISSN 2622-4771

https://jurnal.stie-aas.ac.id/index.php/IJEBAR

level of efficiency ratio obtained a percentage of $3.80 \%$ so that it can be said that the collection of Land and Building Tax (PBB) conducted by the Regional Finance Agency (BKD) of Suko Harjo is included in the very efficient criteria because the percentage is less than $5 \%$.

b. In 2017 the fee for collecting Land and Building Tax (PBB) is set at Rp. 1,500,000,000 with the realization of Land and Building Tax (PBB) revenue of Rp. 36. 104,224,831 and the level of efficiency ratio obtained a percentage of $4.15 \%$ so it can be said that the collection of Land and Building Tax (PBB) conducted by the Regional Finance Agency (BKD) of Sukoharjo Regency is included in the very efficient criteria because the percentage is less than $5 \%$.

c. In 2018 the cost of collecting tax on land and Building Tax (PBB) set amount Rp.1.500.000.000 with the realization of revenue from land and building tax (PBB) Rp. 36,005,474,311 and the level of efficiency ratio obtained a percentage of $4.16 \%$ so it can be said that the collection of Land and Building Tax (PBB) conducted by the Regional Finance Agency (BKD) of Sukoharjo Regency is included in the very efficient criteria because the percentage is less than $5 \%$.

The average efficiency ratio in 2016-2018 if calculated at $4.04 \%$ so that the efficiency ratio shows into the criteria of very efficient or the performance of the collection of Land and Building Tax (PBB) conducted by the Regional Financial Board (BKD) Sukoharjo Patu District including the criteria are very efficient because the percentage is less than 5\%. It happened where the realization of the Land and Building Tax (PBB) in Sukoharjo Regency in 2016-2018 was greater than the cost of collecting the Land and Building Tax (PBB). The results of this study are consistent with the research of Agustin Rahayu and Abdul Halim (2016) which states that the efficiency of the management of the Land and Building Tax (PBB) in the DPDPK of the City of Yogyakarta in the first year of management is $2.99 \%$ with very efficient efficiency criteria.

\subsection{The Effect of Land and Building Tax (PBB) Effectiveness Ratio in Sukoharjo Regency in 2016-2018}

To find out the magnitude of the ratio of the effectiveness of the Land and Building Tax (PBB) is calculated by comparing the realization of the receipt of the Land and Building Tax (PBB) with the target of receiving the Land and Building Tax (PBB) that has been set. If the calculation of the effectiveness of the Land and Building Tax (PBB) produces a percentage exceeding $100 \%$, then the Land and Building Tax is included in the highly effective criteria or the collection of the Land and Building Tax (PBB) in Sukoharjo Regency is very good and if the result is less than $75 \%$ then it is included in the criteria ineffective. The following is the calculation of the effectiveness of the Land and Building Tax (PBB) in the Sukoharjo patent in 2016-2018:

a. In 2016

$$
\frac{\text { Rp. } 35.480,427.946}{\text { Rp. } 27.000,000,000} \times 100 \%=131,41 \%
$$

b. 2017

$$
\frac{\text { Rp. } 36.104 .224 .831}{\operatorname{Rp} .30 .000 .000 .000} \times 100 \%=120,35 \%
$$

c. 2018

$$
\frac{\text { Rp. } 36.005 .474 .311}{\text { Rp. } 30.000 .000 .000} \times 100 \%=120,02 \%
$$


International Journal of Economics, Business and Accounting Research (IJEBAR)

Peer Reviewed - International Journal

Vol-4, Issue-2, 2020 (IJEBAR)

E-ISSN: 2614-1280 P-ISSN 2622-4771

https://jurnal.stie-aas.ac.id/index.php/IJEBAR

The magnitude of the ratio of the effectiveness of Land and Building Tax (PBB) revenue from 2016-2 018 can be seen in table 8 .

Table 8 Effectiveness Ratio of Land and Building Tax in Sukoharjo Regency in 2016-2018

\begin{tabular}{|c|c|c|c|c|}
\hline Year & $\begin{array}{c}\text { UN target } \\
(\mathrm{Rp})\end{array}$ & $\begin{array}{c}\text { United Nations } \\
\text { realization } \\
(\mathrm{Rp})\end{array}$ & $\begin{array}{c}\text { Effectiveness } \\
\text { Ratio } \\
(\%)\end{array}$ & Criteria \\
\hline 2016 & $27,000,000,000$ & $35,480,427,946$ & 131.41 & Very effective \\
\hline 2017 & $30,000,000,000$ & $36,104,224,831$ & 120.35 & Very effective \\
\hline 2018 & $30,000,000,000$ & $36,005,474.311$ & 120.02 & Very effective \\
\hline \multicolumn{3}{|c|}{ Average } & 123.93 & Very effective \\
\hline
\end{tabular}

Source: (Regional Finance Agency of Sukoharjo Regency)

Based on table 8 and the results of the calculation of the effectiveness ratio of Land and Building Tax (PBB) in Sukoharjo Regency in 2016-2018 can be explained as follows:

a. In 2016 the target of receiving Land and Building Tax (PBB) revenue is set to be Rp. 27,000,000,000 with the realization of Land and Building Tax (PBB) revenue of Rp. 35,480,427,946 and the level of effectiveness ratio obtained a percentage of $131.41 \%$ so it can be said that the collection of Land and Building Tax (PBB) conducted by the Regional Finance Agency (BKD) of Sukoharjo Regency is included in the very effective criteria because the percentage is above $100 \%$.

b. In 2017 the target of receiving Land and Building Tax (PBB) is set at Rp. 30,000,000,000 with the realization of Land and Building Tax (PBB) revenue of Rp. 36,104,224,831 and the level of effectiveness ratio obtained a percentage of $120.35 \%$ so that it can be said that the collection of Land and Building Tax (PBB) conducted by the Regional Finance Agency (BKD) of Sukoharjo Regency is included in the very effective criteria because the percentage is above $100 \%$.

c. In 2018 the target of receiving Land and Building Tax (PBB) is set at Rp. 30,000,000,000 with the realization of Land and Building Tax (PBB) revenue of Rp. 36,005,474,311 and the level of effectiveness ratio obtained a percentage of $120.02 \%$ so that it can be said that the collection of Land and Building Tax (PBB) conducted by the Regional Finance Agency (BKD) of Sukoharjo Regency is included in the very effective criteria because the percentage is above $100 \%$.

The average effectiveness ratio in 2016-2018 when calculated is $123.93 \%$ so that the effectiveness ratio shows that it is a very effective criterion or collection of Land and Building Tax (PBB) conducted by the Regional Financial Board (BKD) Sukoharjo Regency included in the criteria very effective because the percentage is above $100 \%$. This happened where the realization of land and building tax (PBB) revenue in Sukoharjo Regency in 2016-2018 was greater than the target of land and building tax (PBB) revenue. The results of this study are consistent with the research of Raudhatun Wardhani \& Wida Fadhila (2017) which states that the effectiveness of Land and Building Tax (PBB) revenue in Aceh Besar District has increased every year with an average percentage of $100.10 \%$ with very effective criteria. 4.3 The Influence of Land and Building Tax (PBB) Contribution Ratio in 2016-2018 Sukoharjo
Regency 
International Journal of Economics, Business and Accounting Research (IJEBAR)

Peer Reviewed - International Journal

Vol-4, Issue-2, 2020 (IJEBAR)

E-ISSN: 2614-1280 P-ISSN 2622-4771

https://jurnal.stie-aas.ac.id/index.php/IJEBAR

To find out the magnitude of the contribution ratio of the Land and Building Tax (PBB) is calculated by comparing the realization of the Land and Building Tax (PBB) revenue with the realization of the Regional Original Income Receipt (PAD). If the calculation of the ratio of the contribution of the Land and Building Tax (PBB) to Regional Own Revenue (PAD) produces a percentage of no more than $10 \%$, then the Land and Building Tax (PBB) is included in the criterion is very less and what if the result is more than $50 \%$ then included in the criteria very good. The following is the calculation of the contribution of the Land and Building Tax (PBB) in Sukoharjo Regency in 2016-2018:

a. In 2016

$$
\frac{R p \cdot 35.480 .427 .946}{\operatorname{Rp} .335 .071 .057 .676} \times 100 \%=10,59 \%
$$

b. 2017

$$
\frac{\text { Rp. } 36.104 .224 .831}{\text { Rp. } 395.975 .464 .962} \times 100 \%=9,12 \%
$$

c. 2018

$R p_{x} 36.005 .474 .311$

$\frac{\text { Rp. } 290.125 .644 .997}{100 \%=12,41 \%}$

The magnitude of the ratio of contribution of the adoption of Land and Building Tax (PBB) from 2016-2018 can be seen in table 9 .

Table 9 Ratio of Contribution of Land and Building Taxes to Sukoharjo Regency's Original Local Revenue (PAD) in 2016-2018

\begin{tabular}{|c|c|c|c|c|}
\hline Year & $\begin{array}{c}\text { United Nations } \\
\text { realization } \\
(\mathrm{Rp})\end{array}$ & $\begin{array}{c}\text { Realization of } \\
\text { PAD } \\
(\mathrm{Rp})\end{array}$ & $\begin{array}{c}\text { Contribution } \\
\text { Ratio } \\
(\%)\end{array}$ & Criteria \\
\hline 2016 & $35,480,427,946$ & $335,071,057,676$ & 10.59 & Less \\
\hline 2017 & $36,104,224,831$ & $395,975,464,962$ & 9,12 & Very less \\
\hline 2018 & $36,005,474,311$ & $290,125,644,997$ & 12.41 & Less \\
\hline \multicolumn{3}{|c|}{ Average } & 10,71 & Less \\
\hline
\end{tabular}

Source: (Regional Finance Agency in Sukoharjo Regency)

Based on table 9 and the results of the calculation of the contribution ratio of the Land and Building Tax (PBB) to Regional Original Revenue (PAD) in Sukoharjo Regency in 2016-2018 can be explained as follows:

a. In 2016 the realization of revenue from the Land and Building Tax (PBB) was set at Rp. 35,480,427,946 with the realization of Regional Original Revenue (PAD) of Rp. 335,071,057,676 and the level of contribution ratio obtained a percentage of $10.59 \%$ with less criteria because of the percentage ratio of the ratio o contribution between 10.10$20 \%$

b. In 2017 the realization of revenue from the Land and Building Tax (PBB) is set at Rp. 36,104,224,831 with the realization of Regional Original Revenue (PAD) of Rp. 395,975,464,962 and the level of contribution ratio obtained a percentage of $9.12 \%$ with very less criteria because the percentage ratio of the contribution ratio is less than $10 \%$.

c. In 2018 the realization of revenue from the Land and Building Tax (PBB) is set at Rp. 36,005,474,311 with the realization of Regional Original Revenue (PAD) of 
International Journal of Economics, Business and Accounting Research (IJEBAR)

Peer Reviewed - International Journal

Vol-4, Issue-2, 2020 (IJEBAR)

E-ISSN: 2614-1280 P-ISSN 2622-4771

https://jurnal.stie-aas.ac.id/index.php/IJEBAR

Rp. 290,125,644,997 and the level of contribution ratio gets a percentage of $12.41 \%$ with less criteria because the percentage interval of contribution ratio between 10.10-20\%

The results of the analysis can be concluded that the realization of the receipt of Land and Building Tax (PBB) to Regional Original Revenue (PAD) in Sukoharjo Regency in 2016-2018 has decreased and increased or fluctuated with an average contribution ratio of $10.71 \%$ so that the ratio the contribution shows less criteria because the interval is between $10.10-20 \%$. The results of this study are consistent with research by Nur Anisa, Elva Nuraina \& Liana Vivin Wihartanti (2019) which states that the contribution of the Land and Building Tax (PBB) to the Regional Original Revenue (PAD) is included in the criteria less because of the average contribution ratio in 2015 -2018 in Magetan Regency by 10.08\%.

\section{Closing}

\subsection{Conclusion}

Based on the results of research conducted by the author on Efficiency Ratios, Effectiveness Ratios, Ratio of Land and Building Tax Contributions (PBB) to Regional Original Revenue (PAD) in Sukoharjo Regency in 2016-2018 it can be concluded that:

1. The level of efficiency ratio of Land and Building Tax (PBB) revenue in Sukoharjo District in 2016-2018 as a whole shows very efficient criteria with an average of $4.04 \%$. This is because in 2016-2018 the realization of revenue from the Land and Building Tax (PBB) is greater than the total costs incurred each year, which means that Sukoharjo Regency is already good and optimal in utilizing the collection fees.

2. The level of effectiveness ratio of Land and Building Tax (PBB) revenue in Sukoharjo Regency in 2016-2018 as a whole shows a very effective criteria with an average of $123.93 \%$ which means that the Regional Government of Sukoharjo Regency has succeeded in achieving its goal in realizing the Land Tax and Building (PBB).

3. The level of contribution ratio of the receipt of the Land and Building Tax (PBB) to the Regional Own Revenue (PAD) in Sukoharjo Regency in 2016-2018 on average is included in the criteria of less than $10.71 \%$ with details in 2016 of $10.59 \%$ in 2017 it was $9.12 \%$ while in 2018 it was $12.41 \%$. This causes that Sukoharjo regency is lacking in optimizing the sources of land and building tax revenues (PBB) which causes the contribution to the Regional Original Revenue (PAD) to be lacking.

\subsection{Suggestion}

Based on the conclusions made above, the authors provide the following suggestions:

1. Future studies are expected to conduct more extensive research by adding research variables in order to compare the potential or prospects of receiving Land and Building Tax (PBB) in Sukoharjo Regency or certain regions with the potential or prospects of the Land and Building Tax (PBB) in other regions.

2. The Sukoharjo Regency Regional Financial Board (BKD) should provide counseling on the importance of paying taxes and exploring the potential of the region to increase the inclusion of Regional Original Revenue (PAD).

3. The Local Government in Sukoharjo Regency should regularly collect taxpayers' data not only by looking at the data but directly plunging into the field so that the data obtained is more correct and clearer. 
International Journal of Economics, Business and Accounting Research (IJEBAR)

Peer Reviewed - International Journal

Vol-4, Issue-2, 2020 (IJEBAR)

E-ISSN: 2614-1280 P-ISSN 2622-4771

https://jurnal.stie-aas.ac.id/index.php/IJEBAR

\section{References}

Adelina Rima. (2011). Analysis of the effectiveness and contribution of land and building tax revenue to the revenue of the district of Gresik. E-Journal of Accounting, Surabaya State University , 1 (87), 1-20.

Agung Purwolaksono. (2010). Analysis of the Effectiveness and Efficiency of Land and Building Tax Collection

Akhsan, M., Economics, F., Business, AND, Islam, U., \& Alauddin, N. (2014). The influence of the contribution of land and building tax on local original income in the city of Makassar .

Anisa, N., et al (2019). Analysis of Effectiveness and Contribution of PBB-P2 to Increase Local Revenue of Magetan Regency. Journal of Economic Education. Vol.7. No.2

Effi ciency, A., Taxes, dank, and, B., Rural, B., \& Cities, AND (2018). Analysis of efficiency, effectiveness, and contribution of land and building tax in rural and urban areas (pbb-p2) to regional original income .

Puspita, Elfayang Rizky Ayu (2014). Analysis of the Effectiveness, Efficiency, and Contribution of Taxes and Regional Levies Against PAD Blora Regency in 2009-2013 Thesis . 1-77.

Hasan, M. (2017). Contribution of Land and Building Taxes to Local Revenue Levels in Regional Revenue Offices in Makassar City. Economix Journal , 5 (2), 70-81

Indah K., et al (2016). Analysis of the Effectiveness and Strategy of Receiving Land and Building Taxes in Rural Office Buildings (PBB-P2) in the Office of Financial Management of Revenue and Assets, South Minahasa Regency. Ju rnal Periodically , 16 (04), 763-772.

Ismail, M., et al (2006). The Relative Efficiency of the Land and Building Tax Service Office (KP PBB) in East Java. Indonesian Journal of Economics and Business. Vol. 211, No. 3 299-316

Maahmudi. 2010. Regional Financial Management. Jakarta: Erlangga Publisher.

Ma'ruf, M. H., \& Supatminingsih, S. (2020). Faktor-faktor yang Berpengaruh Terhadap Kepatuhan Wajib Pajak Dalam Membayar Pajak Bumi Dan Bangunan. Jurnal Akuntansi dan Pajak, 20(2), 276-284.

Mardiasmo. 2013. Taxation. 2013 revised edition. Yogyakarta: Andi.

Decree of the Minister of Home Affairs No. 690,900,327 concerning guidelines for financial valuation and performance

Polli, Sumena. (2014). Analysis of the Effectiveness and Growth of Land and Building Tax Revenues and Their Contribution to Regional Revenues in the City of Manado. EMBA Journal, Vol.2 No.4. Pages 751-761

Prathiwi, IAMA, et al (2015). Analysis of Land and Building Tax Revenue Strategy for Rural and Urban Cities (PBB P2) and the Effectiveness of its Administration in Denpasar City Government in 2013-2014. E-Journal S1 Ak of Ganesha University of Education. Vol. 3, No. 1 
International Journal of Economics, Business and Accounting Research (IJEBAR)

Peer Reviewed - International Journal

Vol-4, Issue-2, 2020 (IJEBAR)

E-ISSN: 2614-1280 P-ISSN 2622-4771

https://jurnal.stie-aas.ac.id/index.php/IJEBAR

Putra, KYA, et al (2017). Effectiveness of Land and Building Tax Revenues in Rural and Urban Areas (PBB P2) and the Contribution of Land and Urban Taxes and Rural and Urban Taxes (PBB P2) Against Local Revenue (PAD). Scientific Journal of Accounting and Humanika, Vol. 7 No. 2

Rahayu, HA, Halim, A. (2016). Evaluation of Land and Building Tax Management in Rural and Urban Studies in the Yogyakarta Government . Journal of Management Research. Vol. 3, No1.

Ryfal, Y, and Sri, A (2015). Analysis of the Effectiveness, Efficiency of Regional Taxes and Regional Levies as well as Contributions to the Original Revenue of Bantul Regency in 20092014. Accounting , 3 (2), 1-20.

Saputro, R., et al (2014). The Effectiveness of Land and Building Tax Revenues in Rural and Office Buildings (PBB P2) Against Increased Revenue of Original Local Revenue (PAD). Surabaya. Journal of Business Administration

Sugiyono 2016. Quantitative, qualitative and R\&D research methods. Bandung: PT Alfabet.

Law No. 28 of 2007 concerning General Provisions for Taxation

Law No. 28 of 2009 concerning PAD

Law No. 28 of 2009 concerning Regional Taxes

Download g-Law No. 33 of 2004 concerning Financial Balance between the Central Government and Regional Governments

Law N0. 69 of 2010 concerning Procedures for the Granting and Utilization of Regional Tax Collection and Levies Incentives

Wardhani, R, and F, Wilda (2017). Analysis of the Effectiveness of Land and Building Tax Revenues in Rural and Urban Areas and Their Contribution to Original Regional Revenues in Aceh Besar District. Scientific Journal of Accounting Economics Students (JIMEKA). Vol. 2, No.3. $10-17$

Wicaksono, G, and Pamungkas, TE (2017). Analysis of the Effectiveness and Contribution of Land and Building Taxes in Rural and Urban Areas (PBB-P2) Against Regional Original Revenue (PAD) at Jember Regency. Jurnal STIE Semarang Vol 9 No. 1 